\title{
A Family of Rat CRMP Genes Is Differentially Expressed in the Nervous System
}

\author{
Li-Hsien Wang and Stephen M. Strittmatter \\ Departments of Neurology and Neurobiology, Yale University School of Medicine, New Haven, Connecticut 06510
}

\begin{abstract}
Members of the collapsin/semaphorin family play an important role in creating the complex pattern of neuronal connectivity. Inhibition of growth cone motility by chick collapsin is mediated by the intraneuronal protein CRMP-62. We have now isolated four rat sequences that are highly related to chick CRMP-62. All four genes are expressed exclusively in the nervous system and primarily during development. Rat CRMP-2/TOAD-64 is most closely related to chick CRMP-62 and is the most widely expressed CRMP within the nervous system. Rat CRMP-1 and CRMP-4/rUlip are expressed during discrete periods of neuro-
\end{abstract}

nal development and are not found in the adult nervous system. Rat CRMP-3 has a distinct distribution, being expressed transiently in developing spinal cord and selectively in the postnatal cerebellum. The differential expression of these genes suggests that CRMPs may transduce signals from different semaphorins and that semaphorins may regulate the plasticity of the adult nervous system.

Key words: CRMP; TOAD-64; semaphorin; collapsin; Ulip; gene expression; neurodevelopment
After their final mitosis, neurons migrate, differentiate, and extend axons to appropriate synaptic targets. Axonal pathfinding requires recognition of cell-surface, matrix-bound, and soluble factors by the distal tip of the neurite, the growth cone (Strittmatter, 1995). Some factors promote growth cone motility, and others inhibit it. The growth cone can be characterized as a specialized sensory apparatus transforming environmental signals into directed growth.

The critical role of inhibiting factors in neural development has been appreciated only recently through detailed studies of visual system formation and through the development of a growth cone collapse assay (Bonhoeffer and Gierer, 1984; Kapfhammer and Raper, 1987). Raper and colleagues have partially purified a 100 $\mathrm{kDa}$ chick brain protein as a growth cone collapsing factor (Luo et al., 1993). The deduced amino acid sequence of this protein, collapsin, bears homology to those of a family of insect semaphorin proteins that participate in axonal pathfinding (Kolodkin et al., 1993). Recombinant collapsin potently collapses the growth cones of dorsal root ganglion (DRG) neurons, but not those of retinal neurons (Luo et al., 1993).

We searched for molecules that might be involved in collapsin action by expression cloning in Xenopus laevis oocytes (Goshima et al., 1995). The expression of RNA from one embryonic day 7 (E7) chick DRG cDNA clone yielded a current response in voltage-clamped oocytes after bath application of recombinant collapsin. This clone encodes a novel, cytosolic protein of $62 \mathrm{kDa}$ termed CRMP-62 (for Collapsin Response Mediator Protein-62). Injection of CRMP-62 protein renders oocytes collapsin-

\footnotetext{
Received Feb. 15, 1996; revised June 19, 1996; accepted July 17, 1996.

This work was supported by grants to S.M.S. from National Institutes of Health, and from the Spinal Cord Research Fund of the Paralyzed Veterans of America. S.M.S. is a John Merck Scholar in the Biology of Developmental Disorders in Children. We thank Fumio Nakamura, P. Strittmatter, and R. Kalb for helpful discussions, and Ling $\mathrm{Li}$ for excellent technical assistance.

Correspondence should be addressed to Dr. Stephen M. Strittmatter, Departments of Neurology and Neurobiology, Yale University School of Medicine, P.O. Box 208018, 333 Cedar Street, New Haven, CT 06510.

Copyright (C) 1996 Society for Neuroscience $0270-6474 / 96 / 166197-11 \$ 05.00 / 0$
}

responsive within minutes, indicating that the protein functions directly in a collapsin-response pathway. Antibodies to the CRMP-62 protein can be introduced into oocytes and chick DRG neurons. Cells containing anti-CRMP antibodies do not respond to collapsin, indicating that CRMP-62 is required for the collapsin signaling process. It has been proposed that CRMP-62 is an intracellular component of the multimeric receptor complex that couples collapsin-binding transmembrane receptors to the signaling machinery.

CRMP-62 shares sequence homology to unc-33, a nematode gene required for appropriately directed axonal extension ( $\mathrm{Li}$ et al., 1992; Goshima et al., 1995). Two human fetal brain cDNAs as well as a rat protein, TOAD-64 (for turned on after division) (Minturn et al., 1995) and a mouse protein, Ulip (for unc-33-like phosphoprotein) (Byk et al., 1996) display significant sequence similarity with CRMP-62, indicating that multiple CRMP-related genes may exist in mammals. The recent expansion of the collapsin/semaphorin family suggests that neurons may require more than one CRMP to transmit different signals (Luo et al., 1995; Puschel et al., 1995). In this study, we have identified four CRMPrelated proteins from rat brain cDNA, designated rCRMP-1, rCRMP-2, rCRMP-3, and rCRMP-4. All rCRMPs are expressed selectively in neural tissues. Each of the rCRMPs has a unique transcript and displays a distinct expression pattern during development. We propose that the expression of one or more of four CRMPs enables neurons to respond to the diverse signals of the collapsin/semaphorin gene family during development.

\section{MATERIALS AND METHODS}

Materials. The following reagents were obtained from Sigma (St. Louis, MO): phenol (P1037), nitro blue tetrazolium (NBT, N-6876), 5-bromo4-chloro-3-indolyl phosphate (BCIP, B-8503), sheep serum (S-7773), and levamisole (L-9756). NEBlot random Priming kit and restriction enzymes were from New England BioLabs (Beverly, MA). Alkaline phosphatase-conjugated anti-digoxigenin Fab fragment (1093274), digoxigenin-11-UTP (1209256), and Taq DNA polymerase were purchased from Boehringer Mannheim (Indianapolis, IN). Guanidine thiocyanate was from American Bioanalytical (Natick, MA). Hybond N nylon membrane was obtained from Amersham (Arlington Height, IL). 
Radiolabeled $\left[\alpha-{ }^{32} \mathrm{P}\right] \mathrm{dCTP}\left(\mathrm{NEG} 01-{ }^{3} \mathrm{H}\right)$ was from DuPont NEN (Boston, MA). MEGAscript T7 and SP6 transcription kits were purchased from Ambion (Austin, TX). Adult rat brain cDNA library cloned in pcDNA-1 vector $\left(1 \times 10^{6}\right.$ independent clones $)$ and TA cloning kit were obtained from Invitrogen (San Diego, CA). General chemicals were from Sigma or J. T. Baker, Inc. (Phillipsburg, NJ) and were of molecular biology grade.

Isolation of $r C R M P-1, r C R M P-2$, and $r C R M P-3 c D N A s$. The characterization of hCRMP-1 and hCRMP-2 sequences has been described previously (Goshima et al., 1995). A partial sequence for hCRMP-3 was determined in a similar manner by sequencing the plasmid encoding an additional human EST (GenBank M85617). An adult rat brain cDNA library was screened with four different random primed ${ }^{32} \mathrm{P}$-labeled probes. The first probe was the entire hCRMP-1 sequence. To create the second probe, we synthesized oligonucleotides corresponding to the hCRMP-2 coding strand from -5 to +19 and the noncoding strand from +1719 to +1692 . These oligonucleotides amplified a $1.7 \mathrm{~kb}$ band by PCR using rat brain cDNA library as a template. This PCR product was gel-purified and used as probe. The third probe of $0.45 \mathrm{~kb}$ was also created by PCR with rat brain cDNA library as template. The sense primer of the third probe corresponded to all possible codons for the amino acid sequence at position 362-369 of hCRMP-3, and the antisense primer consisted of all possible codons for the amino acid sequence at position 514-507 of hCRMP3 (numbering relative to homologous amino acids in CRMP-62). The fourth probe consisted of the rCRMP-4 derived from the degenerate PCR reaction described in the next section. By standard hybridization methods at high stringency, the first probe allowed isolation of the rCRMP-1 sequence; the second, rCRMP-2; the third, rCRMP-3; and the fourth, rCRMP-4. None of the probes detected other CRMPs after washing steps in $0.1 \times \mathrm{SSC}, 0.1 \%$ SDS at $63^{\circ} \mathrm{C}$.

Isolation of other CRMP sequences by degenerate RT-PCR. To detect other CRMP sequences, we conducted PCR amplification with two degenerate primers. The antisense primer corresponds to residue 380 389 of CRMP-62: $5^{\prime}$-gai gc[a/g] tti gti [c/g][t/a]i gti aci gci ac[g/a] aa-3'. This oligonucleotide will hybridize without mismatches to unc-33, CRMP-62, rCRMP1, rCRMP-2, rCRMP-3, hCRMP-1, hCRMP-2, and hCRMP-3. The sense primer corresponds to residues 24-34 of CRMP62: $5^{\prime}$-ati gti aa[t/c] ga[t/c] ga[t/c] ca[a/g] [a/t]ii tt[t/c] ta[t/c] gci ga- $3^{\prime}$. This oligonucleotide will hybridize with no mismatches to CRMP-62, rCRMP-2, and hCRMP-2, with one mismatch to rCRMP-1 and rCRMP-3 and four mismatches to unc-33. The expected PCR product from CRMPlike sequences is $1.1 \mathrm{~kb}$ in length. As template we utilized either an adult rat brain cDNA library or cDNA derived from neonatal rat brain mRNA. The cDNA was synthesized by MMLV reverse transcriptase with the antisense degenerate CRMP oligonucleotide as primer. With both templates, a single major band $1.1 \mathrm{~kb}$ was detected after 30 cycles of PCR with an annealing temperature of $42^{\circ} \mathrm{C}$. This $1.1 \mathrm{~kb}$ band was eluted from the gel and ligated into the pCRII vector. Multiple independent colonies

\begin{abstract}
H-1 ...SDRLLIK GGRIINDDQS LYADVYLEDG LIKOIGENLI VPGGVDTIEA NGRMVIPGGI DVNTYLRPS QGMTAADDFF QGTRAALVGG R-1 MSHQGKKSIP HITSDRLLIR GGRI INDDQS FYADVYLEDG LIKQIGENLI VPGGVKTIEA NGRMVIPGGI DVNTYLQKPS QGMTSADDFF QGTRAALAGG H-2 MSYQGKKNID RITSDRLIIK GGKIVINDDOS FYADIYMEDG LIKQIGENLI VPGGVKTिIEA HSRMVIPGGI DVHTRFQMPD QGMTSADDFF QGTKAALAGG R-2 MSYQGKKNIP RITSDRLLIK GGKIVNDDQS FYADIYMEDG LIKQIGENLI VPGGVKTIEA HSRMVIPGGI DVHTRFQMPD QGMTSADDFF QGTKAAL.AGG CH MSYOGKKNIP RITSDRLLIK GGKIVNDDOS FYADIYMEDG LIKOIGENLI VPGGVKTIEA HGRMVIPGGI DVHTRFOMPE OGMTSADDFF QGTKAALAGG R-3 …IP RITSDRLLIK GGKIVNDDQS FHADLYVEDG LIKQIGENLI VPGGIKTIDA HGLMVLPGGV DVHTRLQMPV LGMTPADDFC QGTKAALAGG R-4 MSYQGKKNIP RITSDRLLIK GGRIVNDDQS FYADIYMEDG LIKQIGDNLI VPGGVKTIEA NRKMVMPGGI DVHTHFQMPY KGMTTVDDFF QGTKAALAGG
\end{abstract}

H-1 TTMIIDHVVP EPGSSLLTSF EKWHEAADTK SCCDYSLHVD ITSNYDGVRE ELEVLVQDKG VNSFQVYMAY KDVYQMSDSQ LYEAFTFLKG LGAVILVHAE R-1 TTMIIDHVVP EPGSSLLTSF EKWHEAADTK SCCDYSLHVD ITSWYDGVRE ELEVLVQDKG VNSFQVYMAY KDLYQMSDSO LYEAFTFLKG LGAVILVHAE H-2 TTMIIDHVVP EPGTSLLAAF DQWREWADSK SCCDYSLHVD ISEWHKGIQE EMEALVKDHG VNSFLVYMAF KDRFQLTDCQ IYEVLSVIRD IGAIAQVHAE R-2 TTMIIDHVVP EPGTSLLAAF DQWREWADSK SCCDYSLHVD ITEWHKGIQE EMEALVKDHG VNSELVYMAF KDRFQLTDSQ IYEVLSVIRD IGAIAQVHAE CH TTMIIDHVVP EPGTSLITAF DOWREWADSK SCCDYSLHVD ITEWHKGVOE EMEAIJVKDHG VNSFLVYMAF KDRFQLSDSQ IYEVLSVIRD IGATAQVHAE R-3 TTMILDHVFP DAGVSLLAAY EOWRERADSA ACCDYSLHVD IPRWHESTKE ELFALVRDKG VNSFLVFMAY KDRCOCTDEQ IYEIFSLIRD LGAVAQVHAE R-4 TTMIIDHVVP EPESSLTEAY EKWREWADGK SCCDYALHVD ITHNDDSVKQ EVQNLSKEKG VNSFMVYMAY KDLYQVSNTE LYEIFTCLGE LGAIAQVHAE

H-1 NGDLIAQEQK RILEMGITGP EGHALSRPEE LEAEAVFRAI TIAGRINCPV YITKVMSKSA ADIIALARKK GPLVFGEPIA ASLGTDGTHY WSKNWAKAAA R-1 NGDLIAQEQK RILEMGITGP EGHALSRPEE LEAEAVFRAI AIAGRINCPV YITKVMSKSA ADIIALARKK GPLVFGEPIA ASLGTDGTHY WSKNWAKAAA H-2 NGDIIAEEQQ RILDLGITGP EGHVLSRPEE VEAEAVNRAI TIANQTNCPL YITKVMSKSS AEVIAOARKK GTVVYGEPIT ASLGTDGSHY WSKNWAKAAA R-2 NGDIIAEEQQ RILDLGITGP EGHVLSRPEE VEAEAVINRSI TIANQTNCPL YVTKVMSKSA AEVIAQARKK GTVVYGEPIT ASLGTDGSHY WSKNWAKAAA $\mathrm{CH}$ NGDIIAEEQQ RILELGITGP EGHVLSRPEE VEAEAVNRAI TIANQTNCPL YITKVMSKSA AEVIAQARKK GTVVYGEPIT ASLGTDGSHY WSKNWAKAAA $\mathrm{H}-3$ HY W. KNWAKAAA R-3 NGDIVEEEQK RLLEQGITGP EGHVLSHPEE VEAEAVYRAV TIAKQANCPL YITKVMSKGA ADMVAQAKRR GVVVFGEPIT ASLGTDGSHY WSKNWAKAAA R-4 NGDIIAQEQA RMLEMGITGP EGHVLSRPEE LEAEAVFRAI TVASQTNCPL YVTKVMSKSA ADLISQARKK GNVVFGEPIT ASLGIDGTHY WSKNWAKAAA

H-1 FVTSPPLSPD PTTPDYLTSL LACGDLQVTG SGHCPYSTAQ KAVGKDNFTL IPEGVINGIEE RMTVVWDKAV ATGKMDENQF VAVTSTNAAK IFNLYPRKGR R-1 FVTSPPLSPD PTTPDYLTSL LACGDLQVTG SGHCPYSTAQ KAVGKDNFTL IPEGVNGIEE RMTVVWDKAV ATGKMDENQF VAVTSTNAAK IFNLYPRKGR H-2 FVTSPPLSPD PTTPDFLNSL LSCGDLOVTG SAHCTFNTAO KAVGKDNFTL IPEGTNGTEE RMSVIWDKAV VIGKMDENQF VAVTSTNAAK VFNLYPRKGR R-2 FVTSPPLSPD PTTPDFLNSL LSCGDLQVTG SAHCTFNTAQ KAVGKDNFTL IPEGTNGTEE RMSVIWDKAV VTGKMDENQF VAVTSTNAAK VFNLYPRKGR CH FVTSPPLSPD PTTPDFLNSL LSCGDLQVTG SAHCTENTAQ KAVGKDNFTL IPEGTNGTEE RMSIIWDKAV VTGKMDENQF VAVTSTNAAK IFNLYPRKGR H -3 .VTSPFVNPD PT.ADH.TC. LSSGDLQVTG SAHCTFTTAQ KAVGKDNF L TPEGTNGVEE RMSMVWEKCV .SGKMDENEF VAVTSTN... IFNFYPRKGR R-3 FVTSPPINPD PTTADHLTSL LSSGDLQVTG SAHCTFTTAQ KAVGKDNFTL IPEGINGIEE RMSVWWEKCV ASGKMDENEF VAVTSTNAAK IFNFYPRKGR R-4 FVTSPPLSPD PTTPDYINSL LASGDLQLSG SAHCTFSTAQ KAIGKDNFTA IPEGTNGVEE RMSVIWDKAV ATGKMDENQ

H-1 IAVGSDADV IWDPDKLKTI TAKSHKSAVE YNIFEGMECH GSPLVVISOG KIVFEDGNIN VNKGMGRFIP RKAFPEHLYQ RVKIRNKVFG LQGVSRGMYD R-1 IAVGSDADVV IWDPDKMKTL TAKSHKSTVE YNIFEGMECH GSPLVVISOG KIVFEDGNIS VSKGMGRFIP RKPFPEHLYQ RVRIRSKVFG LHSVSRGMYD H-2 IAVGSDADLV IWDPDSVKTI SAKTHNSSLE YNIFEGMECR GSPLVVISOG KIVLEDGTIH VTEGSGRYIP RKPFPDFVYK RIKARSRLAE LRGVPRGLYD R-2 ISVGSDADLV IWDPDSVKTI SAKTHNSALE YNIFEGMECR GSPLVVISQG KIVLEDGTLH VTEGSGRYIP RKPFPDFVYK RIKARSRLAE LRGVPRGLYD $\mathrm{CH}$ IAVGSDADLV IWDPDSVKTI SAKTHNISLE YNIFEGMECR GSPLVVISOG KIVLEDGNLH VTEGSGRYIP RKPFPDFVYK RIKARSRLAE LRGVPRGLYD H-3 VAVGSDADLV IWNPKATKII SAKTHNINVE. NIFEGVVER GAPPVVISGA RVALEDGKMF VTPGAGRFVP RKTFPDFVYK RIKARNRLAE IHGVPRGLYD R-3 VAVGSDADLV IWNPRATKVI SAKSHNLNVE YNIFEGVECR GMPTVVISQG RVVLEDGNLL VTPGAGRFIP RKTFPDFVYK RIKARNRLAE IHGVPRGLYD

H-1 GPVHEVPATP KYATPAPSAK SSPSKHOPPP IRNLHQSNES LSGAQIDDNN PRRTGHRIVA PPGGRSNITS LG R-1 GPVYEVPATP KHAAPAPSAK SSPSKHOPPP IRNLHQSNFS LSGAQIDDNN PRRTGHRIVA PPGGRSNITS LG H-2 GPVCEVSVTP KTVTPASSAK TSPAKQQAPP VRNLHQSGFS LSGAQIDDNI PRRTTQRIVA PPGGRANITS LG R-2 GPVCEVSVTP KTVTPASSAK TSPAKQQAPP VRNLHQSGFS LSGAQIDDNI PRRTTQRIVA PPGGRANITS LG CH GPVCEVSVTP KTVTPASSAK TSPAKQQAPP VRNLHQSGFS LSGAQIDDNI PRRTTQRIVA PPGGRANITS LG H-3 GPVHEVMVPA KPGSGAPARA SCPGKISVPP VRNLHQSGES LSGSQADDHI ARRTAOKIMA PPGGR...

R-3 GPVHEVMLPA KPGSGTQARA SCPGK ISVPP VRNLHQSGES LSGSQADDHI ARRTAQKIMA PPGGRSNITS LS

Figure 1. Amino acid alignments of CRMP-related proteins. The deduced amino acid sequence for four rat CRMP-related genes (R-1, R-2, R-3, and R-4) and three human CRMP-related genes (H-1, H-2, and H-3) is compared with CRMP-62 ( $\mathrm{CH})$. Those residues that differ from the consensus are shown in bold type. GenBank accession numbers for R-1, R-2, and R-3 are U52102, U52103, and U52104, respectively. 
were derived from each cDNA template. Clones were analyzed by restriction digest with BamHI, BglII, EcoRI, and PstI. The restriction patterns corresponded to those predicted for rCRMP-1, rCRMP-2, rCRMP-3, or to a single novel sequence. The DNA sequence of one clone with the novel pattern was determined and designated rCRMP-4.

$R N A$ isolation and Northern blot. Cellular RNA was extracted from rat tissues at the indicated developmental stages using the acid guanidium thiocyanate/phenol/chloroform method (Chomczynski and Sacchi, 1987). Fifteen micrograms of total RNA were separated on $1 \%$ agaroseformaldehyde gel and transferred onto Hybond $\mathrm{N}$ nylon membrane by capillary elution with $20 \times$ SSC. CRMP cDNA probes were prepared by random priming with $\left[\alpha-{ }^{32} \mathrm{P}\right] \mathrm{dCTP}$. Hybridization was performed as described previously (Goshima et al., 1995). Washed nitrocellulose membranes were enclosed in Saran wrap and exposed to Kodak X-Omat film for $6-36 \mathrm{hr}$ with Lightning plus intensifying screen at $-80^{\circ} \mathrm{C}$.

In situ hybridization. Rats were killed by $\mathrm{CO}_{2}$ inhalation. Whole embryos or dissected brains were immediately frozen on dry ice. Frozen tissues were stored in sealed containers at $-80^{\circ} \mathrm{C}$ or embedded in TBS freezing medium for further processing. Cryosections (12-20 $\mu \mathrm{m}$ thick) were prepared with a Carl Zeiss cryostat (Model HM505; Thornwood, NY) and thaw-mounted on Superfrost plus glass slides (Fisher Scientific, Houston, TX). After being dried on a $60^{\circ} \mathrm{C}$ slide warmer, sections were fixed in $3.7 \%$ formaldehyde/PBS at room temperature for $60 \mathrm{~min}$ and dehydrated with sequential exchanges into 50 and $70 \%$ ethanol. Sections could be stored in $70 \%$ ethanol at $4{ }^{\circ} \mathrm{C}$ for up to 4 weeks without affecting the results. Digoxigenin-labeled probes were prepared with plasmids containing CRMP cDNA inserts using digoxigenin UTP and MEGAscript in vitro transcription kits, as described by the manufacturer. Riboprobes were diluted in hybridization solution (50\% formamide, 5\% SSC, pH 7.0, $50 \mu \mathrm{g} / \mathrm{ml}$ yeast tRNA, 50 $\mu \mathrm{g} / \mathrm{ml}$ heparin, $1 \%$ SDS). Optimal probe concentration was determined by serial dilution. Sections were air-dried before adding probes. Diluted probes were applied onto the sections, and then clean coverslips were overlaid to spread the solution evenly. Slides were incubated at $60^{\circ} \mathrm{C}$ in a sealed container overnight. Posthybridization wash was performed as described previously (Wilkinson and Nieto, 1993). In brief, sections were washed twice in solution I (50\% formamide, $5 \%$ SSC, $1 \%$ SDS) at $60^{\circ} \mathrm{C}$ for $60 \mathrm{~min}$ each, followed by three $20 \mathrm{~min}$ washes in solution II ( $0.5 \mathrm{M} \mathrm{NaCl}, 10 \mathrm{~mm}$ Tris, $\mathrm{pH} 7.5,0.1 \%$ Tween 20$)$ at room temperature. After treating with $25 \mu \mathrm{g} / \mathrm{ml}$ RNase A in solution II at $37^{\circ} \mathrm{C}$ for $45 \mathrm{~min}$, sections were washed sequentially with solution II for $10 \mathrm{~min}$ at room temperature, solution III $(50 \%$ formamide, $2 \times$ SSC) for $1 \mathrm{hr}$ at $60^{\circ} \mathrm{C}$, and PBST (100 mM Na-phosphate, pH 7.4, 150 $\mathrm{mm} \mathrm{NaCl}, 0.1 \%$ Tween 20) for $30 \mathrm{~min}$ at room temperature. Sections were blocked with $10 \%$ sheep serum in PBST at room temperature. Alkaline phosphatase-conjugated anti-digoxigenin Fab was diluted at 1:1000 in PBST containing 1\% sheep serum and preabsorbed with E11 chick embryo powder for $2 \mathrm{hr}$ at $4^{\circ} \mathrm{C}$. After centrifuging at $12,000 \mathrm{rpm}$ for $10 \mathrm{~min}$, preabsorbed antibody solution was applied to the sections. Slides were then incubated at $4^{\circ} \mathrm{C}$ overnight in humidified chambers. Sections were thoroughly washed the next day and incubated with NTMT (100 mm NaCl, $100 \mathrm{~mm}$ Tris, $\mathrm{pH} 9.5,50 \mathrm{~mm} \mathrm{MgCl}_{2}, 2 \mathrm{~mm}$ Levamisole, $0.1 \%$ Tween 20$)$ containing NBT $(0.34 \mathrm{mg} / \mathrm{ml})$ and BCIP $(0.175 \mathrm{mg} / \mathrm{ml})$. Slides were stored in the dark at room temperature for 6-30 hr. Sections were observed and photographed using an Olympus microscope (Model BX50) with Kodak Tmax 400 film.

\section{RESULTS}

\section{Identification of CRMP-related sequences}

CRMP-62 was isolated from a chick embryonic dorsal root ganglion library by expression cloning of a factor required for collapsin-induced changes in $X$. laevis oocyte membrane conductance. Comparison of the CRMP-62 with DNA sequence databanks indicates that several human expressed sequence tags (ESTs) with high homology to CRMP-62 exist (Goshima et al., 1995). We determined the full-length sequence for three of these ESTs and partial sequence for a fourth. A number of other ESTs are identical to portions of these full-length human CRMPrelated sequences. These data identify three human CRMPrelated proteins, all of which are highly related to CRMP-62 (Fig. 1, Table 1). We termed these sequences hCRMP-1, hCRMP-2, and hCRMP-3 (partial sequence). CRMP-62 is most closely related to hCRMP-2 (98\% amino acid identity). hCRMP-1 shares $78 \%$ amino acid sequence identity with hCRMP-2 and $66 \%$ sequence identity with hCRMP-3. hCRMP-2 and hCRMP-3 share $76 \%$ identity.

To facilitate analysis of the functional consequences of this sequence diversity and to explore whether other CRMP-related genes exist, we examined rat brain cDNA for CRMP-related sequences. As a first step, we screened a rat brain cDNA library with probes derived from each of the three human CRMP-related genes. For each, we isolated 7-18 independent clones and then determined the DNA sequence of the clone with the longest insert. With hCRMP-1 and hCRMP-2 as probes, we obtained full-length sequences for rCRMP-1 and rCRMP-2. With hCRMP-3 as probe, we obtained an rCRMP-3 sequence that appears to encode all but 8 residues at the $\mathrm{N}$ terminus of the protein. Each human CRMP-derived probe was specific for the

\section{Table 1. The relatedness of CRMP sequences}

\begin{tabular}{|c|c|c|c|c|c|c|c|c|c|c|}
\hline & hCRMP-1 & rCRMP-1 & hCRMP-2 & $\begin{array}{l}\text { rCRMP-2/ } \\
\text { TOAD-64 }\end{array}$ & c-CRMP-62 & hСRMP-3 & 1CRMP-3 & $\begin{array}{l}\text { ICRMP-4/ } \\
\text { rUlip }\end{array}$ & mUlip & $20 x-33$ \\
\hline hCRMP-1 & - & & & & & & & & & \\
\hline rCRMP-1 & 97 & - & & & & & & & & \\
\hline hCRMP-2 & 78 & 78 & - & & & & & & & \\
\hline $\begin{array}{l}\text { rCRMP-2/ } \\
\text { TOAD-64 }\end{array}$ & 79 & 79 & 99 & - & & & & & & \\
\hline c-CRMP-62 & 77 & 77 & 98 & 98 & - & & & & & \\
\hline hCRMP-3 & 66 & 66 & 76 & 74 & 74 & - & & & & \\
\hline rCRMP-3 & 68 & 71 & 76 & 76 & 77 & 94 & - & & & \\
\hline $\begin{array}{l}\text { ICRMP-4/ } \\
\text { rUlip }\end{array}$ & 78 & 75 & 74 & 74 & 79 & 79 & 70 & - & & \\
\hline mUlip & 74 & 74 & 76 & 76 & 76 & 64 & 71 & 99 & - & \\
\hline$t a x-33$ & 35 & 36 & 37 & 36 & 36 & 30 & 34 & 35 & 34 & - \\
\hline
\end{tabular}



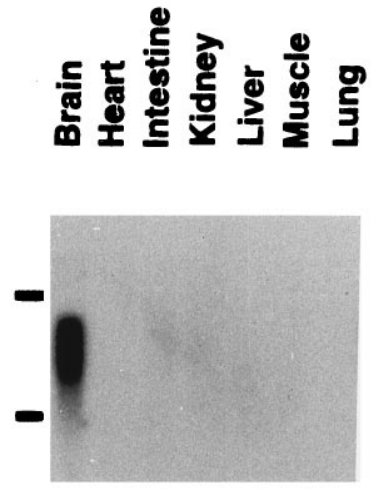

\section{CRMP 1}

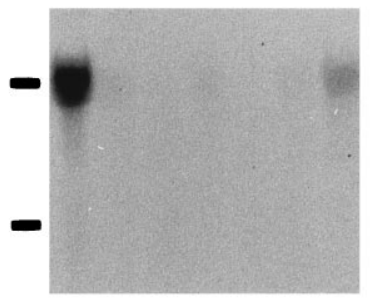

\section{CRMP 2}

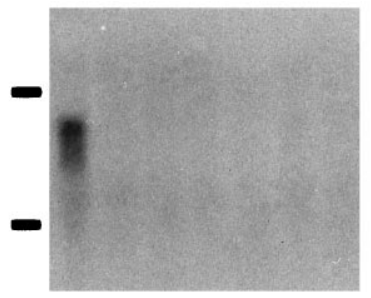

\section{CRMP 3}

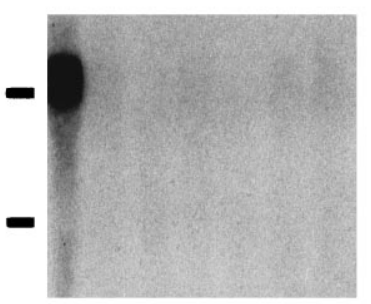

\section{CRMP 4}

Figure 2. Northern analysis of CRMP-related RNAs in various rat tissues. Fifteen micrograms of total RNA from the indicated P1 rat tissues were separated on an agarose-formaldehyde gel, transferred onto nylon membranes, and hybridized to ${ }^{32} \mathrm{P}$-labeled CRMP cDNA probes. The probes were the EagI-Nsi I $2.0 \mathrm{~kb}$ fragment of rCRMP-1 cDNA, the SspI-PstI $1.7 \mathrm{~kb}$ fragment of rCRMP-2 cDNA, the entire $2.5 \mathrm{~kb}$ cDNA fragment of CRMP-3, and the $1.1 \mathrm{~kb}$ PCR product corresponding to amino acids 25-390 of rCRMP-4/rUlip, respectively. RNAs were visualized with ethidium bromide for examining the equivalent amount of each sample. The position of $28 \mathrm{~S}$ and $18 \mathrm{~S}$ ribosomal RNA is shown. Note that the expression of all four CRMPs is neural-specific.

corresponding rat CRMP-related protein. rCRMP-2 is $99 \%$ identical to its human counterpart, rCRMP-1 is $97 \%$ identical, and rCRMP-3 is $94 \%$ identical (Fig. 1, Table 1). The rCRMP-2 sequence identified in this manner is identical to a TOAD-64 sequence isolated by Hockfield and colleagues (Minturn et al., 1995) on the basis of its expression level in two-dimensional gels of developing rat brain.

A PCR-based method was developed to search for other CRMP-related genes. We designed fully degenerate primers containing some inosine residues that were capable of hybridizing to CRMP-1, CRMP-2, and CRMP-3 from chick, rat, and human, as
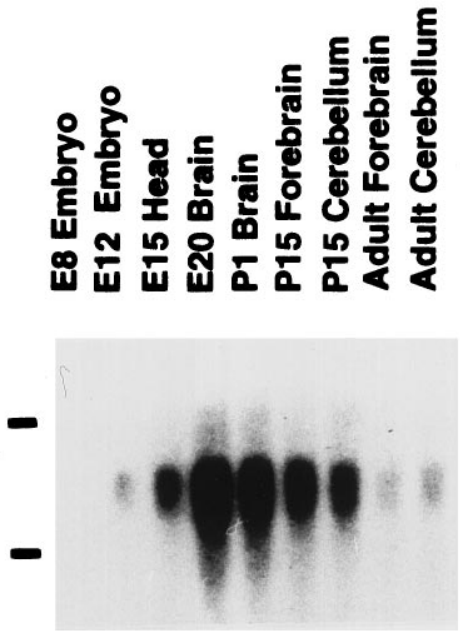

CRMP 1

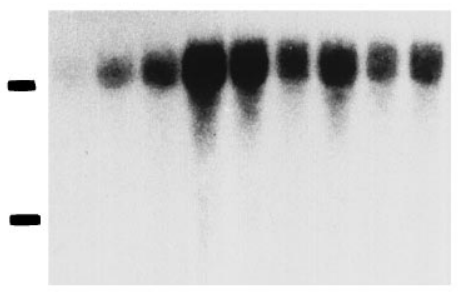

CRMP 2

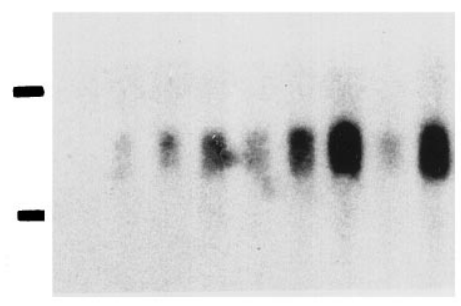

CRMP 3

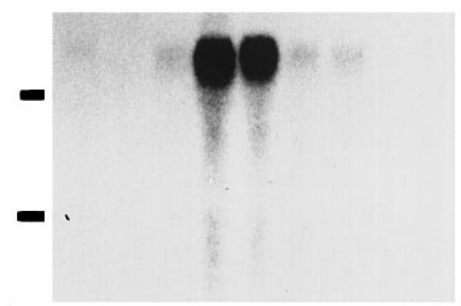

CRMP 4

Figure 3. Northern analysis of rCRMP expression in the developing nervous system. Total RNA from the indicated tissues was prepared. RNA blots were performed as described in Figure 2. The position of $28 \mathrm{~S}$ and $18 \mathrm{~S}$ ribosomal RNA is shown. Note that the expression of rCRMP-3 is specific for cerebellum of postnatal rats. Rat CRMP-2/TOAD-64 has the most persistent expression during development.

well as nematode unc-33. The sense primer is composed of all possible codons for the amino acid residue stretch from 24-34 of CRMP and the antisense primer from residues 380-390. These primers were used to amplify sequences from an adult rat brain cDNA library and for cDNA derived from postnatal day 1 (P1) rat brain mRNA. With both cDNA sources, we obtained a single major product from the PCR reaction with the expected size of 1.1 $\mathrm{kb}$. The amplified DNA was subcloned, and 41 independent clones were analyzed for the sample derived from adult brain cDNA, and 61 clones were analyzed from the neonatal cDNA sample. By restriction digest analysis and Southern blotting, we determined that 24 clones corresponded to rCRMP-1, 58 to 
Table 2. Summary of differential expression of rCRMPs by ISH studies

\begin{tabular}{|c|c|c|c|c|c|}
\hline & & rCRMP-1 & rCRMP-2 & rCRMP-3 & rCRMP-4 \\
\hline \multirow{6}{*}{ E13 } & Forebrain & - & - & - & - \\
\hline & Midbrain & - & - & - & - \\
\hline & Hindbrain & + & + & + & $+/-$ \\
\hline & Spinal Cord-dorsal & - & + & + & - \\
\hline & ventral & + & + & + & - \\
\hline & Dorsal Root ganglia & + & + & + & + \\
\hline \multirow[t]{10}{*}{ E15 } & Neocortex & + & + & - & + \\
\hline & Corpus Striatum & + & ++ & $+/-$ & + \\
\hline & Thalamus & + & + & + & + \\
\hline & Hypothalamus & + & + & + & + \\
\hline & Midbrain & + & + & + & + \\
\hline & Cerebellum & + & + & + & + \\
\hline & Pons & ++ & + & ++ & ++ \\
\hline & Spinal Cord-dorsal & + & ++ & ++ & + \\
\hline & ventral & ++ & ++ & + & ++ \\
\hline & Dorsal Root Ganglia & ++ & ++ & ++ & ++ \\
\hline \multirow[t]{17}{*}{ P1 } & Nasal Epithelium & ++ & ++ & + & ++ \\
\hline & Olfactory Bulb & ++ & ++ & ++ & ++ \\
\hline & Retinal & ++ & ++ & ++ & ++ \\
\hline & Cerebral Cortex & +++ & +++ & $+1-$ & +++ \\
\hline & Hippocampus-Pyramidal cells & +++ & +++ & + & +++ \\
\hline & Granule cells & + & + & $+/-$ & ++ \\
\hline & Corpus Striatum & + & ++ & $+/-$ & ++ \\
\hline & Thalamus & ++ & + & $+1-$ & ++ \\
\hline & Hypothalamus & + & + & - & + \\
\hline & Amygdala & ++ & ++ & - & ++ \\
\hline & Midbrain & ++ & ++ & - & ++ \\
\hline & Cerebellum & + & + & - & + \\
\hline & Pons & ++ & + & - & ++ \\
\hline & Spinal Cord-dorsal & + & + & - & + \\
\hline & ventral & + & + & - & + \\
\hline & Dorsal Root ganglia & ++ & + & + & ++ \\
\hline & Sympathetic ganglia & ++ & + & - & ++ \\
\hline \multirow[t]{6}{*}{ Adult } & Cerebral Cortex & - & + & - & - \\
\hline & Hippocampus-Pyramidal cells & $+1-$ & ++ & - & - \\
\hline & Granule cells & $+/-$ & + & - & - \\
\hline & Cerebellum-Purkinje cells & $+1-$ & + & - & - \\
\hline & Granule cells & - & - & + & - \\
\hline & Dorsal Root Ganglia & + & + & + & + \\
\hline
\end{tabular}

+++ , Dark signal; ++ , average signal; + , weak signal; $+/-$, very weak signal; - , undetectable signal.

rCRMP-2, and 19 to rCRMP-3; 1 was of a unique structure. The sequence of this new PCR-derived sequence is termed rCRMP-4 and is highly related (70-80\% amino acid identity) to rCRMP-1, rCRMP-2, and rCRMP-3 (Fig. 1, Table 1). The broad specificity of the primers and the large number of clones analyzed make the possibility of further rat CRMP-related proteins unlikely. We have rescreened the rat brain cDNA library so as to obtain greater sections of the rCRMP-4 sequence. A clone containing a $1.9 \mathrm{~kb}$ insert that hybridizes with the rCRMP-4 PCR product at high stringency has been isolated. This cDNA sequence encodes the $5^{\prime}$ end of the coding region followed by 400 predicted amino acid residues of the 572 residues observed in other CRMPs. When we used this CRMP-4 partial sequence to search databases, the mouse protein Ulip revealed highest similarity (99\% amino acid identity). Thus, Ulip is likely to be a mouse homolog of rCRMP-4.

The expression of rCRMPs is neural-specific and

\section{developmentally regulated}

Northern blot analysis demonstrates that all four of the rat CRMPs are expressed almost solely in the nervous system (Fig. 2). In contrast, a number of peripheral tissues exhibit no hybridization signal. The only exception to the neural specificity of CRMP expression is the barely detectable level of rCRMP-2/TOAD-64 in lung. The size of the mRNA is $3.0 \mathrm{~kb}$ for rCRMP-1, $4.3 \mathrm{~kb}$ for
rCRMP-2/TOAD-64, $3.2 \mathrm{~kb}$ for rCRMP-3, and $4.5 \mathrm{~kb}$ for rCRMP-4/rUlip. The specificity of the signal was verified by several criteria: (1) the distinct sizes of the mRNA; (2) identical patterns of hybridization with the use of several different probes including some from nonconserved, untranslated regions; (3) detection of cDNA plasmid only for the gene in question; (4) the hybridization of rCRMP-1 probe with mRNA from COS cells transfected with an rCRMP-1 expression vector but not control or rCRMP-2/TOAD-64-transfected cells; and (5) the hybridization of rCRMP-2/TOAD-64 probe with mRNA from COS cells transfected with an rCRMP-2/TOAD-64 expression vector but not control or rCRMP-1-transfected cells. Thus, as for CRMP-62 in chick and unc-33 in nematode, the four rat CRMP genes are likely to participate in uniquely neural functions.

The expression of rCRMP mRNAs was examined at different stages of rat development (Fig. 3). The mRNA for rCRMP-1, rCRMP-2/TOAD-64, and rCRMP-4/rUlip is predominantly expressed during late embryonic life and decreases in abundance shortly after birth. The level of rCRMP-4/rUlip decreases most abruptly and is undetectable by P30. Expression of rCRMP-2/ TOAD-64 persists to the greatest extent, with adult levels being $\sim 15 \%$ of P1 levels. The decline of rCRMP-1 is intermediate between rCRMP-2/TOAD-64 and rCRMP-4/rUlip. The ontogeny 


\section{CRMP1}

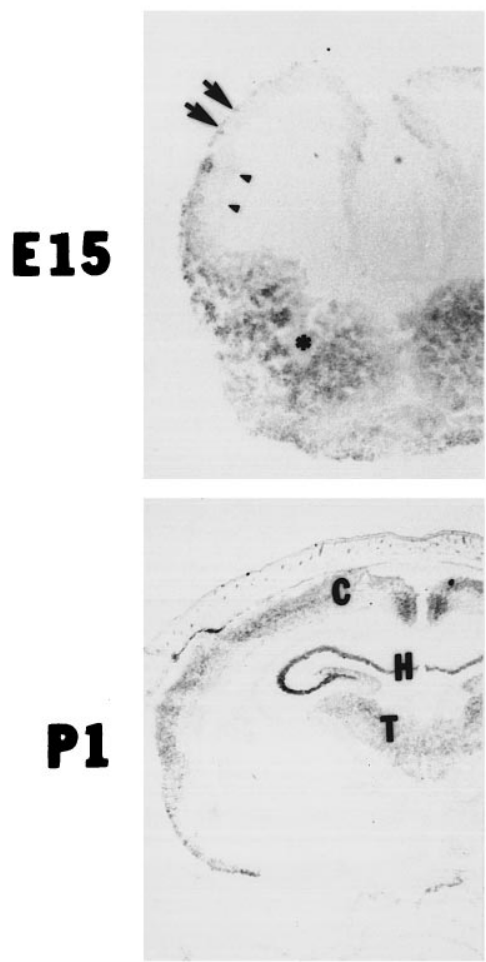

CRMP2
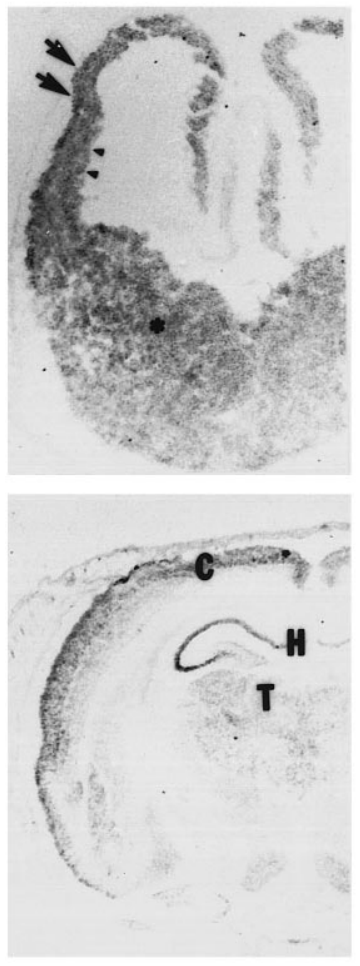

CRMP3

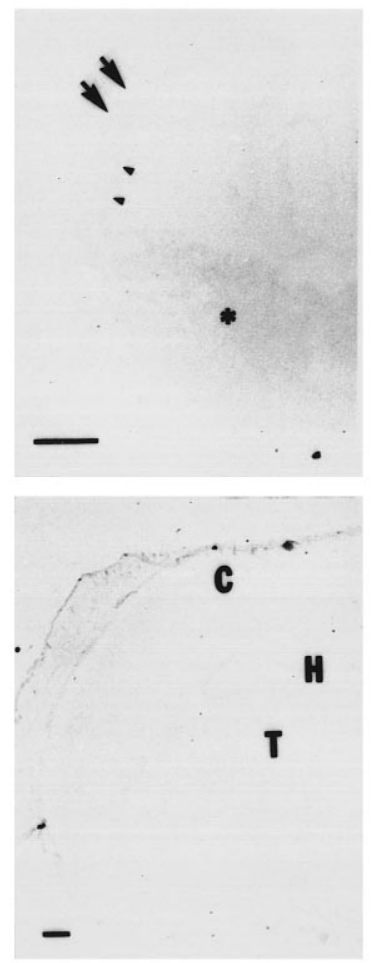

CRMP4
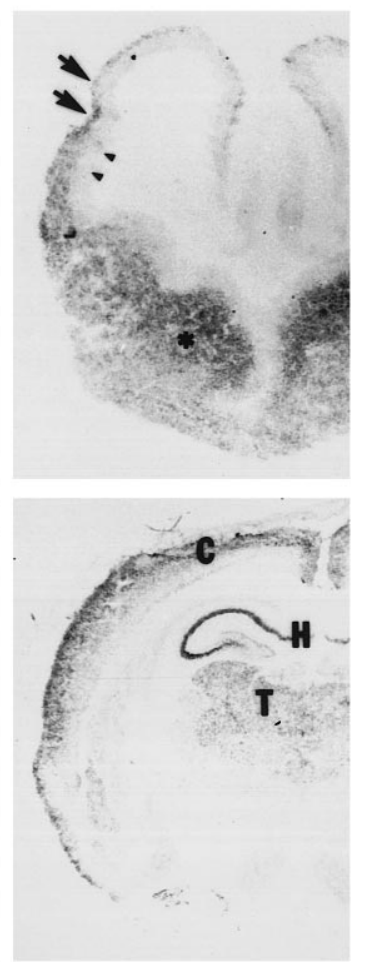

Figure 4. In situ hybridization of rCRMP mRNAs in developing rat forebrain. Coronal sections $(14 \mu \mathrm{m})$ of $E 15$ or $P 1$ rat forebrain were hybridized separately with digoxigenin-labeled antisense riboprobes derived from rCRMP-1, rCRMP-2/TOAD-64, rCRMP-3, or rCRMP-4/rUlip as described in Materials and Methods. The probes were the $B g l \mathrm{II}-N s i \mathrm{I} 1.0 \mathrm{~kb}$ fragment of CRMP-1, the BamHI-EcoRI $1.2 \mathrm{~kb}$ fragment of CRMP-2/TOAD-64, the Pst I-EcoRI $1.3 \mathrm{~kb}$ fragment of CRMP-3, and the $1.1 \mathrm{~kb}$ cDNA fragment corresponding to amino acid residue 25-390 of CRMP-4/rUlip, respectively. At E15, only CRMP-2/TOAD-64 mRNA is expressed in the ventricular zone (arrowhead), whereas the signals of CRMP-1 and CRMP-4/rUlip are detected only in the differentiated neurons (arrow). At P1, the mRNAs of CRMP-1, CRMP-2/TOAD-64, and CRMP-4/rUlip are enriched in the cortex (C), thalamus $(T)$, and hippocampus $(H)$. The pyramidal cells display higher intensity than that of dentate granule cells. The location of basal ganglia is marked by an asterisk. Scale bar, $400 \mu \mathrm{m}$.

of rCRMP-3 expression is distinct. The signal of rCRMP-3 is enriched in cerebellum with maximal expression occurring after birth and with high levels persisting in adulthood.

\section{Differential localization of CRMP isoforms in rat forebrain}

To differentiate the roles of different CRMPs, we have examined further the localization of each rCRMP RNA using in situ hybridization at multiple stages of development. Cryosections were prepared and hybridized with digoxigenin-labeled riboprobes. In all cases, sense riboprobes produced no specific staining.

The expression of four rCRMPs is not detected in the forebrain of E13 and younger embryos (Table 2). In the E15 prenatal forebrain, rCRMP-2/TOAD-64 RNA is widely expressed in the telencephalon, and the staining pattern is uniform (Fig. 4). The signal for rCRMP-2/TOAD-64 mRNA is equivalent in basal ganglia and neocortex. Within the neocortex, the ventricular zone and the marginal zone have largely the same intensity of rCRMP-2/TOAD-64 staining. The signals for rCRMP-1 and rCRMP-4/rUlip are much more limited in the E15 forebrain. Expression of these RNAs is confined to the differentiating neurons and is absent from the ventricular zone (Fig. 4). This restriction of RNA was particularly apparent in the neocortex. The expression of rCRMP-3 is undetectable in the forebrain at this stage. In addition, the staining of all four
rCRMP transcripts is observed in the midbrain, pons, and developing cerebellum at E15 (Table 2).

In the neonatal rat, the expression of rCRMP-1, rCRMP-2/ TOAD-64, and rCRMP-4/rUlip RNA is detected throughout the forebrain, midbrain, pons, and cerebellum (Fig. 4, Table 2). Strong signals are associated with the cortex and pyramidal cells in the hippocampus. Staining of dentate gyrus, thalamus, and basal ganglia is less abundant. The rCRMP-3 probe does not hybridize to the neocortex and hybridizes weakly in the hippocampus.

In the P15 cerebellum, the rCRMP-1 and rCRMP-2/TOAD-64 RNA signals are observed in the external germinal layer, Purkinje cell layer, and granule cell layer (Fig. 5). The expression of rCRMP-3 and rCRMP-4/rUlip is reciprocal; rCRMP-3 RNA is largely distributed in granule cells, and rCRMP-4/rUlip is expressed prominently in external germinal layer. The rCRMP-3 granule cell staining persists through adulthood, whereas the signal of rCRMP-2/TOAD-64 is confined to Purkinje cells in adult. The expression of rCRMP-1 and rCRMP-4/rUlip is reduced by $\mathrm{P} 30$ and is undetectable in adult.

\section{CRMP isoforms expressed in the spinal cord}

In contrast to the forebrain, all four rCRMP mRNAs are expressed in the developing spinal cord by E13. The signals of rCRMP-2/TOAD-64 and rCRMP-3 transcripts are equally de- 


\section{CRMP 1}

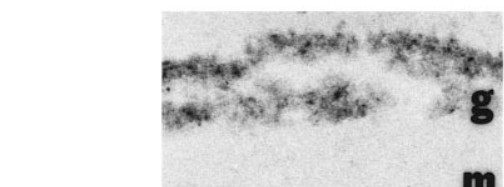

P15
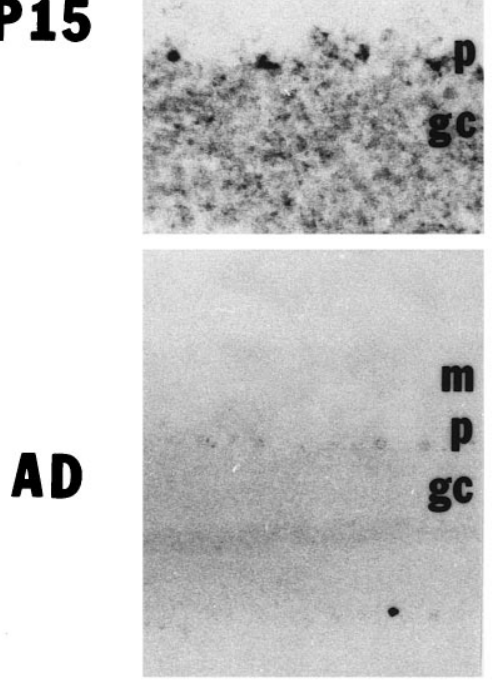

CRMP2
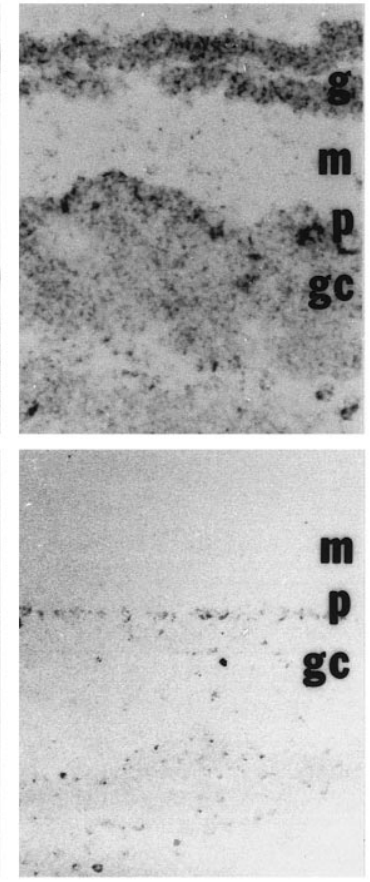

CRMP3
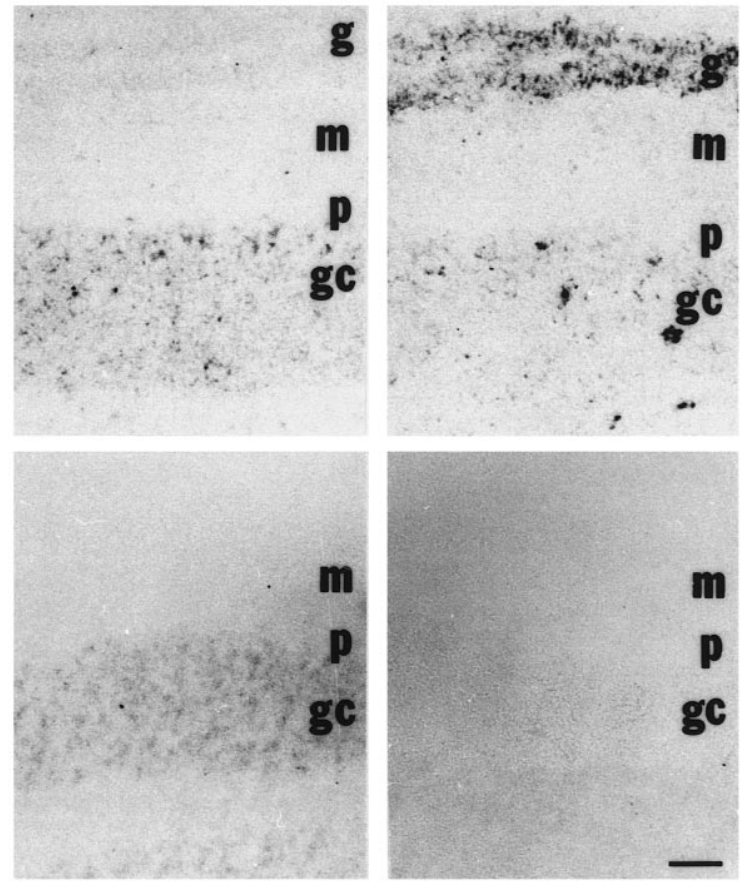

CRMP4

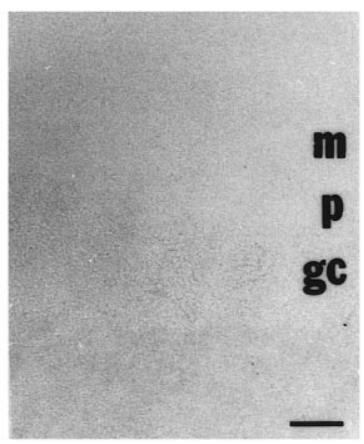

Figure 5. In situ hybridization of rat CRMP mRNAs in cerebellum. Horizontal sections $(14 \mu \mathrm{m})$ of $P 15$ or adult rat $(A D)$ cerebellum were hybridized with digoxigenin-labeled CRMP cRNA probes as described in Figure 4. Note the staining of the external germinal layer $(g)$, the Purkinje cell layer $(p)$, and the granule cell layer $(\mathrm{gc})$. The molecular layer $(\mathrm{m})$ is not stained. Rat CRMP-1 staining is widely distributed at P15 and is markedly decreased in adult. The expression of rCRMP-2/TOAD-64 in Purkinje cells persists through adulthood. rCRMP-3 mRNA is localized primarily to granule cells and is reduced only slightly from P15 to the adult. rCRMP-4/rUlip is expressed primarily in the external germinal layer at P15 and is absent in adult. Scale bar, $100 \mu \mathrm{m}$.

\section{CRMP 1}
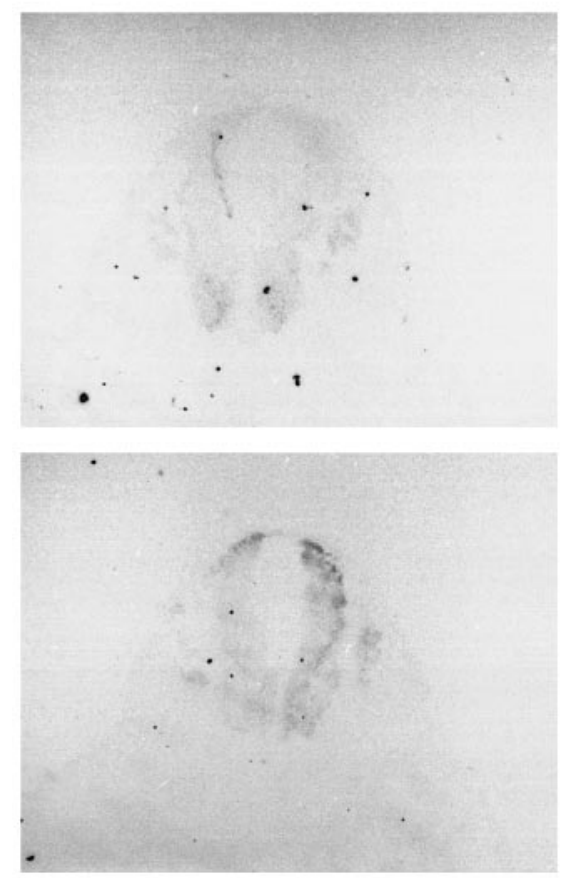

CRMP 3
CRMP 2
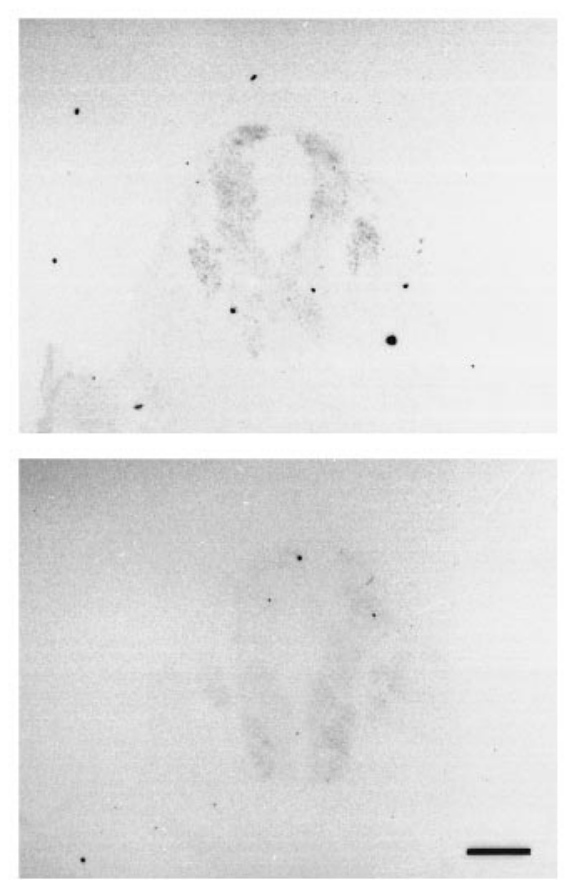

CRMP 4
Figure 6. In situ hybridization of rat CRMP mRNA in E13 developing spinal cord. Cross sections $(14 \mu \mathrm{m})$ of E13 rat embryo were hybridized with digoxigeninlabeled CRMP cRNA probes as described in Figure 4. The staining of rCRMP-2/TOAD-64 and rCRMP-3 mRNA was observed at both dorsal and ventral sides of the spinal cord as well as the DRG. The signals of rCRMP-1 and rCRMP-4/rUlip were less abundant and were limited to the ventral side and DRG. Scale bar, $250 \mu \mathrm{m}$. 
E15

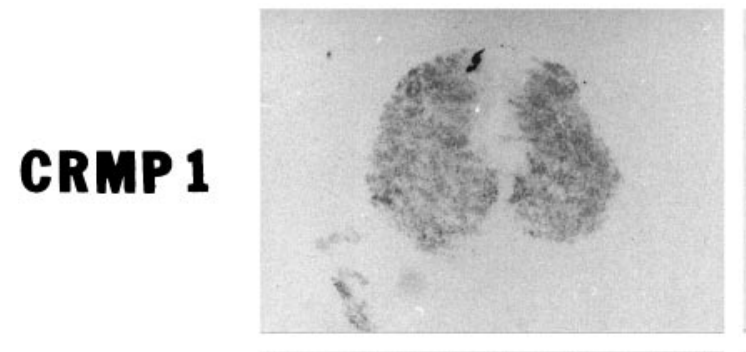

Figure 7. In situ hybridization of rat CRMP mRNAs in developing spinal cord. Cross sections $(14 \mu \mathrm{m})$ of $E 15$ or $P 1$ rat spinal cord were hybridized with digoxigenin-labeled CRMP antisense riboprobes as described in Figure 4. At E15, the strongest signal of CRMP-3 is detected in the dorsal germinal matrix layer, whereas the staining of CRMP-1 and CRMP-4/rUlip is reciprocal to that of CRMP-3. By P1, CRMP-3 signal is undetectable in the spinal cord. Scale bar, $200 \mu \mathrm{m}$.

\section{CRMP 2}

\section{CRMP3}

\section{CRMP4}
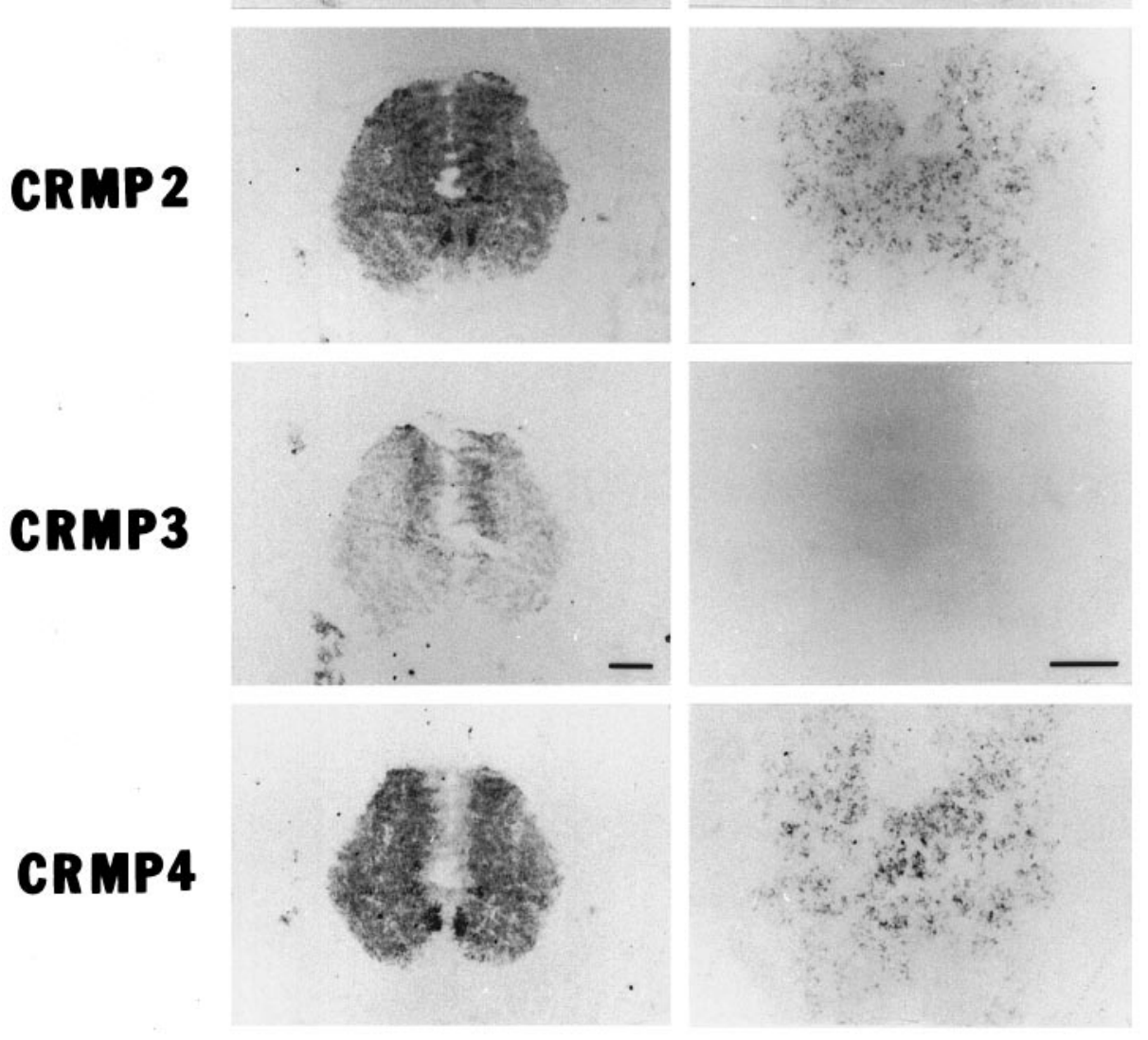

tected at both dorsal and ventral sides, whereas the staining of rCRMP-1 and rCRMP-4/rUlip mRNA is confined to the ventral side and at a lower intensity (Fig. 6). In the E15 developing spinal cord, the four rCRMPs are differentially expressed (Fig. 7). The staining of rCRMP-2/TOAD-64 RNA displays a uniform pattern. The transcript of rCRMP-3 is enriched in the dorsal matrix layer, whereas those of rCRMP-1 and rCRMP-4/rUlip are most abundant outside of the dorsal matrix layer. The expression of rCRMP-3 is reduced to undetectable levels by birth. In the spinal cord of newborn rats, a low level of staining for rCRMP-1, rCRMP-2/TOAD-64, and rCRMP-4/rUlip RNA is observed in the gray matter.

\section{Expression of CRMP isoforms in developing sensory and sympathetic ganglia}

In the peripheral nervous system, all four rCRMP mRNAs are expressed in DRG by E13 and continue to be present in adult DRGs (Figs. 6, 8). The rCRMP-2/TOAD-64 and rCRMP4/rUlip RNAs are detected in nearly all DRG neurons during embryonic development and decrease moderately by adulthood. The expression of rCRMP-1 and rCRMP-3 in DRG is decreased to a greater extent by adulthood, and the staining appears more selective among different adult DRG neurons. The rCRMP-1, rCRMP-2, or rCRMP-4 mRNAs are found in sympathetic ganglia, but the rCRMP-3 RNA is not expressed by sympathetic neurons.

\section{DISCUSSION \\ Four CRMP genes exist in rats}

In this study, we have characterized four members of the CRMP gene family in rat. All four rCRMP genes are expressed predominantly in the nervous system. They are highly related with one another by sequence and are homologous to unc-33, a gene required for appropriate axonal and synaptic organization of neurons in nematode ( $\mathrm{Li}$ et al., 1992). Rat CRMP-2 is identical to rat TOAD-64 (Minturn et al., 1995), and rCRMP-4 is the rat homolog of mouse Ulip (Byk et al., 1996). Both the low-stringency hybridization screening of an adult rat brain cDNA library and the fully degenerate RT-PCR screening of neonatal rat brain RNA did not reveal any additional clones. Thus, it is possible that the 


\section{P1}

\section{CRMP1}

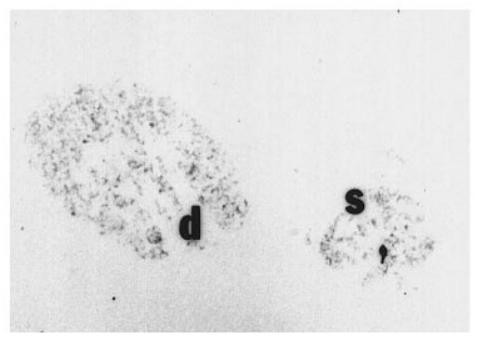

CRMP2

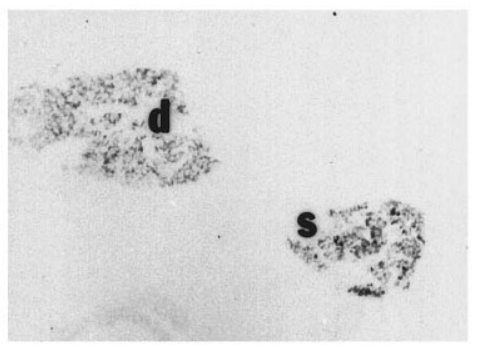

CRMP3
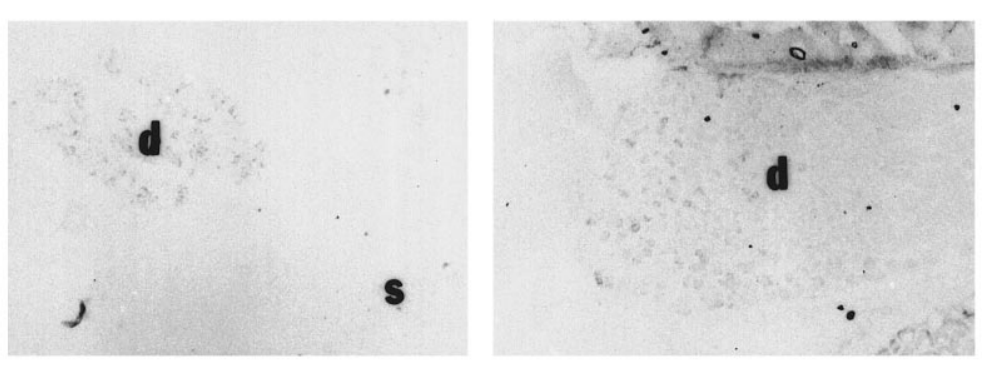

CR MP4

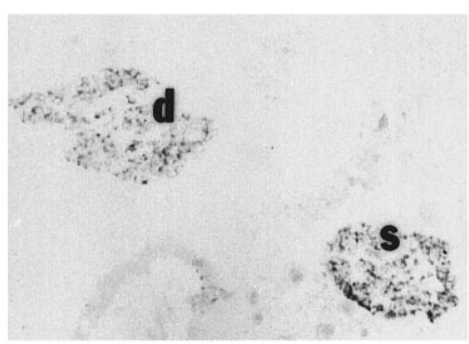

AD
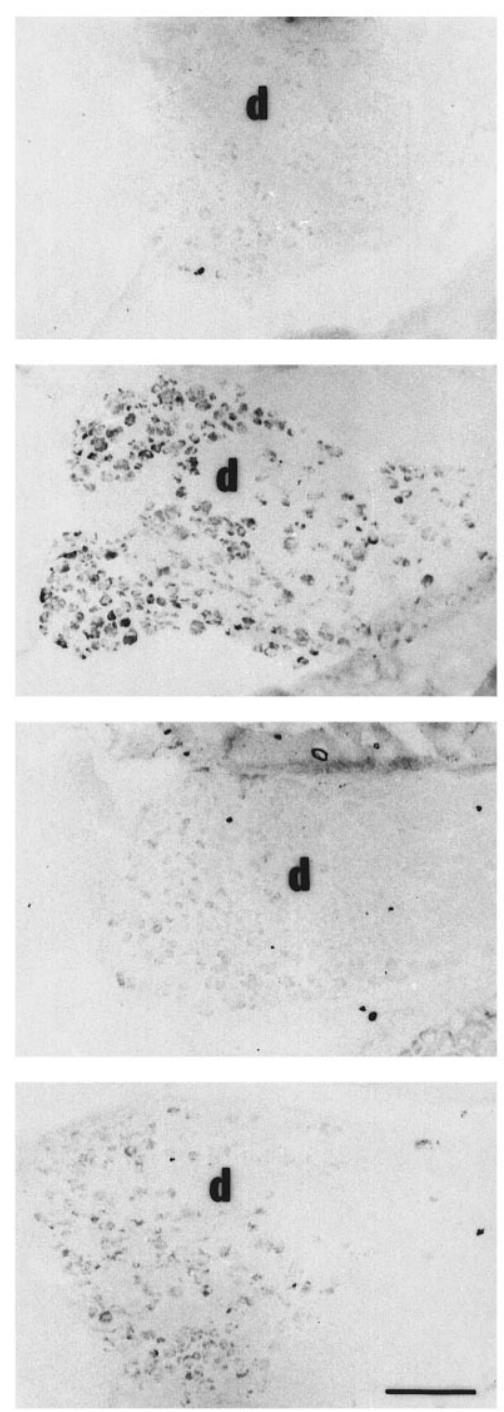

Figure 8. Localization of rat CRMP mRNAs in DRG or sympathetic ganglion neurons by in situ hybridization. Cross sections of the $P 1$ or adult rat $(A D)$ thorax were hybridized with digoxigenin-labeled CRMP cRNA probes as described in Figure 4. DRG (P1 and adult) or sympathetic ganglia (P1) are shown. Note that the rCRMP-3 signal is absent in the P1 sympathetic ganglia $(s)$. The expression of rCRMP-2/ TOAD-64 and rCRMP-4/rUlip is prominent in P1 DRG neurons $(d)$ and persists through adulthood. The mRNA of rCRMP-1 and rCRMP-3 is widely expressed in P1 DRG neurons and is differentially detected in adult DRG neurons. Scale bar, $200 \mu \mathrm{m}$. four rCRMPs represent all CRMP genes expressed in the rat brain.

Additional degrees of CRMP diversity might be created by RNA splicing or by protein post-translational modification. There are three transcripts derived from the unc-33 gene created by alternative splicing at the $5^{\prime}$ end ( $\mathrm{Li}$ et al., 1992). The three mRNAs predict polypeptides with molecular masses of 91, 72, and $56 \mathrm{kDa}$, respectively. CRMP is most similar to the smallest of these proteins. All three nematode polypeptides use the same open reading frame, and they share common $\mathrm{C}$ termini and vary in length at the $\mathrm{N}$ termini. The four rCRMPs are derived from separate genes. Each of the rCRMP genes appears to produce one unique transcript. Although the mRNAs differ in length, each of them predicts a $62 \mathrm{kDa}$ polypeptide. The deduced protein sequences share $75 \%$ homology with one another throughout their length. Antibodies against synthetic CRMP-derived peptides detect a single immunoreactive protein of $62 \mathrm{kDa}$ in rat brain (data not shown). Lysates prepared from chick brain, chick DRG, and PC12 cells exhibit weak CRMP immunoreactivity at higher molecular weights by immunoblotting (Goshima et al., 1995; Byk et al., 1996). Thus, it is possible that unidentified CRMP-related proteins exist in some neurons.
In addition to primary sequence diversity, CRMP protein can be modified post-translationally to increase further the number of CRMP species. The CRMP-4 homolog, Ulip, is found to be phosphorylated in PC12 cells in response to nerve growth factor (Byk et al., 1996). The phenotype of the mutant nematode strain unc-51 is similar to that of unc-33 (Hedgecock et al., 1985). The unc-51 gene encodes a novel protein kinase, and it has been suggested that the function of unc-33 protein may be regulated by the unc-51 kinase (Ogura et al., 1994). To examine the biological significance of phosphorylation, it will be crucial to determine whether the phosphorylation states of CRMPs are altered in neurons exposed to semaphorins (see below).

\section{CRMP genes are differentially expressed in neurons}

The expression of the four rCRMP mRNAs displays distinct temporal and spatial regulation. CRMP-2/TOAD-64 exhibits the most ubiquitous neuronal expression pattern, being present early in development in a majority of neurons and in a selected group of adult neurons, such as pyramidal cells of the hippocampus, Purkinje cells of the cerebellum, and sensory neurons of DRG. CRMP-1 and CRMP-4/rUlip are more stringently regulated during development. Neurons express 
CRMP-1 and CRMP-4/rUlip after migration, with maximal expression during late embryonic and early postnatal stages, and with downregulation postnatally. The expression of CRMP-3 is unique, being limited largely to granule cells in postnatal cerebellum. The persistent expression of CRMP-2/ TOAD-64 and CRMP-3 in adult hippocampus and cerebellum suggests that CRMPs may function in the adult brain as well as during brain development. Both the hippocampus and the cerebellum have been identified as areas with high degrees of synaptic remodeling associated with learning, memory, and plasticity. CRMPs may be part of a group of genes, such as GAP-43, with important roles in growth cone function and neural development that are also selectively expressed in portions of the adult brain that undergo significant synaptic remodeling (Skene, 1989).

\section{The function of CRMPs}

The lack of sequence homology between the CRMP/unc-33 family and other proteins in the databases indicates that the CRMPs may have a unique neuronal function. Based on morphological analysis of mutant worms, the unc-33 protein was speculated to be a structural component of neurons and to be associated with cytoskeleton (Hedgecock et al., 1985). Immunocytochemical staining with anti-CRMP antibody revealed that CRMP distributes in the growth cone, the shaft of axon, and the cell body (Goshima et al., 1995; Minturn et al., 1995; Byk et al., 1996). No distinct cytoskeletal association has been found.

Previous studies indicated that chick CRMP-62 is necessary for a G-protein-mediated transduction of an extracellular collapsin signal into growth cone collapse (Goshima et al., 1995). Based on the observation that the inhibitory effects of antiCRMP antibody can be overcome by the G-protein activator mastoparan, CRMP-62 was postulated to act upstream of a pertussis toxin-sensitive G-protein in the growth cone (Goshima et al., 1995). However, G-protein-independent effects of pertussis toxin on neurite growth and growth cone morphology (Kindt and Lander, 1995) suggest that CRMP-62 might be a component of a non-G-protein-dependent signaling pathway. Identification of a collapsin-binding receptor will greatly facilitate characterization of the signaling pathway in which CRMP-62 participates.

The broad expression pattern of rCRMP mRNAs in developing nervous system suggests that their function may not be restricted solely to collapsin. Collapsin is a member of the expanding semaphorin gene family. In both mouse and chick, there are at least five distinct semaphorins (Luo et al., 1995; Messersmith et al., 1995; Puschel et al., 1995). Some of them are expressed selectively in the spinal cord and may influence the outgrowth of separate populations of sensory neurons. Immunological analysis of semaphorin in grasshopper and genetic analysis in Drosophila suggest that semaphorins regulate axon outgrowth during pathfinding and during target recognition (Matthes et al., 1995). To respond to a multitude of semaphorins, it is conceivable that neurons require intracellular mechanisms to differentiate these signals. The presence of the CRMP gene family may provide this diversity. The simplest explanation for the existence of the CRMP gene family is that different isoforms of CRMP are associated with transduction of signals from different semaphorins. A second explanation is that different CRMPs may couple to various intracellular events stimulated by separate semaphorins. Because functional information for semaphorins other than collapsin-1 is still very limited, we are unable to delineate the relationship between the semaphorin family and the CRMP family at the present time. A third explanation is that multiple CRMPs may mediate the responses of the collapsin/semaphorin family as well as other collapsing factors. Growth cone collapsing activity was identified from components of myelin, tectal membrane extract, brain membrane extract, and selected neurotransmitters (Haydon et al., 1984; Igarashi et al., 1993; McKerracher et al., 1994; Drescher et al., 1995). Whether CRMPs participate in these pathways remain to be determined.

\section{Conclusion}

The importance of CRMP action in CNS development is supported by the finding of a large family of CRMP-related genes in rat. Their differential distribution suggests that they have roles in allowing specific neurons to respond to particular axonal guidance cues. It is likely that these cues are different semaphorins in the extracellular space. Future work will determine which CRMPs are involved in the action of which semaphorins, or whether different CRMPs mediate different intracellular actions for a single semaphorin. The persistent expression of CRMPs in selected areas of the nervous system raises the possibility that some neurons utilize semaphorin/CRMP signaling mechanisms to modulate synaptic plasticity in the adult nervous system.

\section{REFERENCES}

Bonhoeffer F, Gierer A (1984) How do retinal axons find their targets on the tectum? Trends Neurosci 7:378-381.

Byk T, Dobransky T, Cifuentes-Diaz C, Sobel A (1996) Identification and molecular characterization of unc-33-like phosphoprotein (Ulip), a putative mammalian homolog of the axonal guidance-associated unc-33 gene product. J Neurosci 16:688-701.

Chomczynski P, Sacchi N (1987) Single-step method of RNA isolation by acid guanidinium thiocyanate-phenol-chloroform extraction. Anal Biochem 162:156-159.

Drescher U, Kremoser C, Handwerker C, Loschinger J, Noda M, Bonhoeffer F (1995) In vitro guidance of retinal ganglion cell axons by rags, a $25 \mathrm{kDa}$ tectal protein related to ligands for $\mathrm{EPH}$ receptor tyrosine kinases. Cell 82:359-370.

Goshima Y, Nakamura F, Strittmatter P, Strittmatter SM (1995) Collapsin-induced growth cone collapse mediated by an intracellular protein related to UNC-33. Nature 376:509-514.

Haydon PG, McCobb DP, Kater SB (1984) Serotonin selectively inhibits growth cone motility and synaptogenesis of specific identified neurons. Science 226:561-564.

Hedgecock EM, Culotti JG, Thomson JN, Perkins LA (1985) Axonal guidance mutants of Caenorhabditis elegans identified by filling sensory neurons with fluorescein dyes. Dev Biol 111:158-170.

Igarashi M, Strittmatter SM, Vartanian T, Fishman MC (1993) Mediation by $\mathrm{G}$ proteins of signals that cause collapse of growth cones. Science 259:77-79.

Kapfhammer JP, Raper JA (1987) Collapse of growth cone structure with specific neurites in culture. J Neurosci 7:201-212.

Kolodkin AL, Matthews DJ, Goodman CS (1993) The semaphorin gene encodes a family of transmembrane and secreted growth cone guidance molecules. Cell 75:1389-1399.

Li W, Herman RK, Shaw JE (1992) Analysis of the Caenorhabditis elegans axonal guidance and outgrowth gene unc-33. Genetics 132: 675-689.

Luo Y, Raible D, Raper JA (1993) Collapsin: a protein in brain that induces the collapse and paralysis of neuronal growth cones. Cell 75:217-227.

Luo Y, Shepherd I, Li J, Renzi MJ, Chang S, Raper JA (1995) A family of molecules related to collapsin in the embryonic chick nervous system. Neuron 14:1131-1140.

Matthes DJ, Sink H, Kolodkin AL, Goodman CS (1995) Semaphorin II can function as a selective inhibitor of specific synaptic arborization. Cell 81:631-639. 
McKerracher L, David S, Jackson DL, Kottis V, Dunn RJ, Braun PE (1994) Identification of myelin-associated glycoprotein as a major myelin-derived inhibitor of neurite growth. Neuron 13:805-811.

Messersmith EK, Leonardo ED, Shatz CJ, Marc T-L, Goodman CS, Kolodkin AL (1995) Semaphorin III can function as a selective chemorepellent to pattern sensory projections in the spinal cord. Neuron 14:949-959.

Minturn JE, Fryer HJL, Geschwind DH, Hockfield S (1995) TOAD-64, a gene expressed early in neuronal differentiation in the rat, is related to unc-33, a C. elegans gene involved in axon outgrowth. J Neurosci 15:6757-6766.

Ogura K-i Wicky C, Magnenat L, Tobler H, Mori I, Muller F, Ohshima Y (1994) Caenorhabditis elegans unc-51 gene required for axonal elongation encodes a novel serine/threonine kinase. Genes Dev 8:2389-2400.

Puschel AW, Adams RH, Betz H (1995) Murine semaphorin D/collapsin is a member of a diverse gene family and creates domains inhibitory for axonal extension. Neuron 14:941-948.

Skene JHP (1989) Axonal growth associated proteins. Annu Rev Neurosci 12:128-156.

Strittmatter SM (1995) Neuronal guidance molecules: inhibitory and soluble factors. The Neuroscientist 1:255-258.

Wilkinson DG, Nieto MA (1993) Detection of messenger RNA by in situ hybridization to tissue sections and whole mounts. In: Methods in enzymology, Vol 225 (Wasserman PM, DePamphilis ML, eds), pp 361-373. San Diego: Academic. 